\title{
SOME PATHOGENIC BACTERIA OF PUBLIC HEALTH IMPORTANCE IN COW'S MILK SOLD IN MARKETS
}

\author{
ABDOU, M.S. ${ }^{1}$; NAHLA A. EBIED ${ }^{2}$; WALAA M. ELKASSAS ${ }^{2}$ and ADEL M. EL-GAMAL ${ }^{1}$ \\ ${ }^{1}$ Department of Bacteriobiology, Animal Health Research Institute, Kafrelsheikh Branch, Egypt. \\ ${ }^{2}$ Department of Food Hygiene, Animal Health Research Institute, Kafrelsheikh Branch, Egypt.
}

Received: 10 March 2016; $\quad$ Accepted: 29 March 2016

\begin{abstract}
The objective of this study was to determine the incidence of E. coli, Salmonellae, Staph. aureus and Streptococcus species in raw cow's milk and their resistance and sensitivity to nine antibiotics. One hundred raw cow's milk samples were collected from different markets in Kafrelsheikh Governorate which sold uncooled. Aerobic plate count showed a mean value of $4.28 \times 10^{5} \pm 1.23 \times 10^{5} \mathrm{cfu} / \mathrm{ml}$. The results revealed that 72 samples were positive to pathogenic bacteria, 12 isolates of E.coli ( 2 isolates each of $\mathrm{O}_{26}: \mathrm{H}_{11}, \mathrm{O}_{91}: \mathrm{H}_{21}, \mathrm{O}_{124}: \mathrm{H}_{30}$ and $\mathrm{O}_{128}: \mathrm{H}_{2}$ and 4 isolates of $\mathrm{O}_{111}: \mathrm{H}_{2}$ ), 6 isolates of Salmonellae (4 isolates of $S$. typhyimurium and 2 isolates of $S$. infantis), 34 isolates of Staph. aureus and 20 isolates of Streptococcus spp. (St. agalactiae and dysgalactiae (6 isolates for each ), St. uberis (4 isolates), St. pyogenes and St. viridans (2 isolates for each). The isolated strains were subjected to antibiotic sensitivity test which resulted in the highest sensitivity of E.coli to Ciprofloxacin (66.66\%), for Salmonellae, Ciprofloxacin and Gentamicin (66.66\%), for Staph. aureus, Amoxycillin+Clavulonic acid (85.29\%), and for Streptococcus spp., Amoxycillin+Clavulonic acid (90\%). On the other hand the highest resistance of E. coli was to Penicillin P and Clindamycin (100\%), for Salmonellae, Penicillin P and Clindamycin (100\%), for Staph. aureus, Sulphamethoxazole+Trimethoprim (64.70\%) and Streptococcus spp. were to Streptomycin (60\%). Public health importance of the isolated organisms was discussed. Improving hygienic conditions and careful handling of cow during milking should be followed to limit the spread of such bacteria to humans were recommended and limited the use of antibiotics to decrease bacterial resistance.
\end{abstract}

Key words: Public health, raw cow's milk, E. coli, Salmonellae, Staph. aureus, Streptococcus spp.

\section{INTRODUCTION}

Milk and dairy products are basic components of human diet. However, raw milk consumption is accompanied by the risk of ingesting pathogenic bacteria that can pose an elevated health hazard (Latorre et al., 2009). Raw milk may be colonized by a variety of pathogens such as Escherichia coli, Staph. aureus and Salmonella typhimurium. Therefore, they represent an important source of food borne pathogens. These pathogens in milk have been linked to the environment in the farm, mixing clean milk, with mastitic milk and from live stock (Marco and Wells-Bennik, 2008).

E.coli and Salmonellae can contaminate milk through feces, bedding, improperly cleaned teats, milk handling and equipment contaminated with soil or polluted water (Brooks et al., 1991). As the presence

Corresponding author: Dr. WALAA M. ELKASSAS

E-mail address: w.elkasas@yahoo.com

Present address: Department of Food Hygiene, Animal Health Research Institute, Kafrelsheikh Branch, Egypt. of E.coli and Salmonellae in dairy products induce mainly undesirable changes that render the product of inferior quality, unmarketable and unfit for human consumption. Moreover, their presence is frequently considered as reliable index of fecal contamination (Thatcher and Clark, 1978). Outbreak of food borne illnesses following consumption of raw milk and dairy products made from raw milk may be caused by Shiga Toxin - producing E.coli (STEC) and Salmonella spp. (Jayarao et al., 2006). The primary condition associated with cases of food borne illness caused by STEC and Salmonella spp. is gastroenteritis which is usually self-limiting, while immunocompromised individuals were at a higher risk of serious illness. Staph. aureus is one of the major bacterial agents causing food borne diseases in human worldwide (EFSA, 2010). Staphylococcal food poisoning is usually self-limiting and revolves within 24 to $48 \mathrm{~h}$ after onset. Staph. aureus is responsible for diseases caused by exotoxin production and by direct invasion and systemic dissemination such as Bacteremia, septic shock syndrome, skin infection and abscesses (Martineau et al., 2000). 
Staph. aureus and St. agalactic are rarely found outside of the mammary gland, environmental mastitis pathogens (St. uberis and coliforms) can occur in milk as a result of other contributing factors such as dirty cows, poor equipment cleaning and/or poor cooling (Wood, 1992).

Antibiotics are used to treat diseases of cattle, sheep, goat, water buffalo and other animals, as well as used as preservatives for milk (Devriese et al., 1997). The indiscriminate use of antibiotics has led to the development of multiple antibiotic resistances thereby rendering the antibiotic treatment ineffective. Purpose of antibiotic sensitivity testing is to determine the susceptibility of bacteria to various antibiotics. The standardized test is used to measure the effectiveness of a variety of antibiotics on a specific organism in order to prescribe the most suitable antibiotic therapy (Madigan et al., 2000).

Raw milk produced under poor hygienic status harbor great number and different types of bacteria. Therefore, the present study aimed to evaluate the hygienic conditions of raw cow's milk sold in markets in Kafrelsheikh Governorate by screening for the presence of E. coli, Salmonella spp., Staph. aureus, and Streptococcus spp. and their resistance and sensitivity to nine antibiotics.

\section{MATERIALS AND METHODS}

\section{Collection of samples:}

One hundred raw cow's milk samples were collected randomly from different markets in Kafrelsheikh Governorate. The samples were taken into sterile glass bottles and directly transferred to the laboratory in an ice box under hygienic conditions without delay and examined upon arrival.

\section{Aerobic Plate Count (APC):}

The technique was applied by using surface plating method on standard plate count agar according to APHA (2004), $10 \mathrm{ml}$ of raw milk samples were mixed for 2 min with $90 \mathrm{ml}$ of physiological sterile saline in a stomacher to obtain a homogenous dispersion to make a dilution of 1:10. From which further decimal dilutions were prepared for counting.

\section{Isolation and identification of $E$. coli (Bailey and Scott, 1990):}

For the isolation and identification of E. coli, $1 \mathrm{ml}$ of the milk sample was inoculated into MacConkey enrichment broth and incubated at $37^{\circ} \mathrm{C}$ for 24 hours, the positive enriched sample with gas production was cultured on Eosin Methylene Blue (EMB) Agar plates and incubated at $37{ }^{\circ} \mathrm{C}$ for 24 hours. Morphologically, typical colonies (at least 4 / plate) producing metallic sheen on EMB were stabbed into semisolid agar tubes for further identification. Biochemical tests according to Macfaddin (2000) were performed to confirm E. coli using Catalase, Indole, Methyl red, Voges- Proskauer, Nitrate reduction, Urease production, Simon citrate agar and various sugar fermentation tests. The positive isolates were serologically identified according to Kok et al. (1996) by using rapid diagnostic E.coli Set1: O and Set 2: $\mathrm{H}$ antisera sets (DENKA SEIKEN Co., Japan).

\section{Isolation and identification of Salmonellae (Mackie and McCartney, 1989 and Quinn et al. 2004):}

For the isolation and identification of Salmonellae, 1 $\mathrm{ml}$ of the milk sample was inoculated into $10 \mathrm{ml}$ of Rappaport Vassilidis broth (enrichment broth) followed by XLD as selective plating media. The suspected colonies appeared as red colonies with or without black center were identified biochemically and serologically. In general, serological identification of Salmonellae was carried out according to Kauffman - White scheme (Kauffman, 1974) for the determination of somatic (O) and flagellar $(\mathrm{H})$ antigens using Salmonella antiserum (DENKA SEIKEN Co., Japan).

5. Isolation and identification of Staph. aureus as recommended by Mekonnen et al. (2011): $10 \mathrm{ml}$ of raw milk samples were mixed for 2 min with $90 \mathrm{ml}$ of physiological sterile saline in a stomacher to obtain a homogenous dispersion to make a dilution of 1:10. From which further decimal dilutions were prepared for isolation of Staph. aureus by streaking $(0.1 \mathrm{ml})$ of the enriched milk samples on mannitol salt agar and Baird Parker agar supplemented with egg yolk and potassium tellurite and the plate was incubated at 37 ${ }^{\circ} \mathrm{C}$ for 24-48 hours.. Typical coagulase-positive Staph. aureus colonies are yellow colonies surrounded with halo zone on mannitol salt agar or jet black shining convex colonies surrounded by white halo zone, 1-1.5 mm in diameter on Baird Parker agar were considered to be presumptive Staph. aureus. Characteristic colonies were stabbed into semisolid agar tubes for further identification by conventional methods including Gram's stain and various biochemical tests including coagulase test with rabbit plasma, anaerobic utilization of glucose, catalase test, oxidase test, indole, nitrate reduction and hemolysis on sheep blood agar.

\section{Isolation and identification of Streptococcus species as recommended by Carter and Cole (1990).}

The prepared sample was streaked on the surface of Edwards's medium (HIMedia) with add 7\% sheep blood. The inoculated plates were incubated at $37^{\circ} \mathrm{C}$ for 24-48 hours and examined for bacterial growth. Suspected streptococcal colonies (colorless colonies with hemolysis) were sub- cultured, purified and preserved in semisolid agar tubes for further identification. The isolates were initially identified by characteristic morphology and catalase-negative before being subjected for identification by using the 
following tests: hemolysis onto $7 \%$ sheep blood agar, arginine hydrolysis, esculin hydrolysis, sodium hippurate hydrolysis, growth in $6.5 \% \mathrm{NaCL}$ litmus milk, gelatin liquefaction, bile solubility and carbohydrate fermentation tests.

7. Antibiotic Sensitivity testing: was applied according to guide lines stipulated by the international recommendations given by the National Committee for Clinical Laboratory Standards
(NCCLS, 2002) using Muller Hinton agar. Bacterial isolates were tested for their susceptibility to 9 different antimicrobial discs included P: Penicillin (10 IU), S: Streptomycin $(10 \mu \mathrm{g})$, E: Erythromycin $(15 \mu \mathrm{g})$, CD: Clindamycin $(2 \mu \mathrm{g}), \mathrm{G}$ : Gentamicin $(10 \mu \mathrm{g}), \quad$ CIP: Ciprofloxacin $\quad(5 \mu \mathrm{g}), \quad$ SXT: Sulphamethoxazole+Trimethoprim $(25 \mu \mathrm{g})$, AMC: Amoxycillin+Clavulonic acid $(20 \mu \mathrm{g}+10 \mu \mathrm{g}), \mathrm{T}$ : Oxytetracycline $(30 \mu \mathrm{g})$.

\section{RESULTS}

Table 1: Statistical analytical results of Aerobic Plate Count (APC) in raw cow's milk samples ( $\mathrm{n}=100)$.

\begin{tabular}{ccccc}
\hline $\begin{array}{c}\text { No. of +ve } \\
\text { samples }\end{array}$ & $\%$ & \multicolumn{3}{c}{ Count $/ \mathbf{m l}$} \\
\cline { 3 - 5 } & & Min & Max & Mean \pm SE \\
\hline 100 & 100 & $3.76 \times 10^{4}$ & $6.32 \times 10^{6}$ & $4.28 \times 10^{5} \pm 1.23 \times 10^{5}$ \\
\hline
\end{tabular}

Table 2: Incidence of isolation of E. coli, Salmonellae, Staph. aureus and Streptococcus species from the examined raw cow's milk samples $(\mathrm{n}=100)$.

\begin{tabular}{|c|c|c|c|c|c|c|c|c|}
\hline \multirow{3}{*}{$\begin{array}{c}\text { Total No. } \\
\text { of examined } \\
\text { samples }\end{array}$} & \multicolumn{8}{|c|}{ Prevalence of isolated organisms } \\
\hline & \multicolumn{2}{|c|}{ E. coli } & \multicolumn{2}{|c|}{ Salmonellae } & \multicolumn{2}{|c|}{ Staph. aureus } & \multicolumn{2}{|c|}{ Strept. spp } \\
\hline & No. & $\%$ & No. & $\%$ & No. & $\%$ & No. & $\%$ \\
\hline 100 & 12 & 12 & 6 & 6 & 34 & 34 & 20 & 20 \\
\hline
\end{tabular}

Table 3: Incidence and serotyping of $E$. coli isolated from the examined raw cow's milk samples.

\begin{tabular}{|c|c|c|}
\hline \multirow{2}{*}{ E. coli strains } & \multicolumn{2}{|c|}{ No. of isolates } \\
\hline & No. (12/100) & $\%$ \\
\hline $\mathrm{O}_{26}: \mathrm{H}_{11}$ & 2 & 2 \\
\hline $\mathrm{O}_{91}: \mathrm{H}_{21}$ & 2 & 2 \\
\hline $\mathbf{O}_{111}: \mathbf{H}_{2}$ & 4 & 4 \\
\hline $\mathbf{O}_{124}: \mathbf{H}_{30}$ & 2 & 2 \\
\hline $\mathbf{O}_{128}: H_{2}$ & 2 & 2 \\
\hline Total & 12 & 12 \\
\hline
\end{tabular}


Table 4: Incidence and serotyping of Salmonellae isolated from the examined raw cow's milk samples $(\mathrm{n}=100)$.

\begin{tabular}{ccccc}
\hline \multirow{2}{*}{$\begin{array}{c}\text { Salmonella } \\
\text { Serovars }\end{array}$} & No. of isolates & $\%$ & Somatic (O) & Flagellar (H) \\
\cline { 2 - 5 } & Ph I :Ph II \\
\hline S. typhimurium & 4 & 4 & $1,4,5,12$ & $\mathrm{i}: 1,2$ \\
\hline S. infantis & 2 & 2 & 6,7 & $\mathrm{r}: 1,5$ \\
\hline Total & 6 & 6 & & \\
\hline
\end{tabular}

Table 5: Incidence of Gram +ve cocci isolated from the examined raw cow's milk samples $(\mathrm{n}=100)$.

\begin{tabular}{ccc}
\hline \multirow{2}{*}{ Gram +ve cocci } & \multicolumn{2}{c}{ Positive samples } \\
\cline { 2 - 3 } & No. & \% \\
\hline Staphylococcus aureus & 34 & 34 \\
\hline Streptococcus agalactiae & 6 & 6 \\
\hline Streptococcus dysgalactiae & 6 & 4 \\
\hline Streptococcus uberis & 4 & 2 \\
\hline Streptococcus pyogenes & 2 & 2 \\
\hline Streptococcus viridans & 2 & 20 \\
\hline Streptococcus spp. & 20 & 6 \\
\hline
\end{tabular}

Table 6: Susceptibility of Gram negative (E.coli and Salmonellae) to antimicrobial agents.

\begin{tabular}{|c|c|c|c|c|c|c|c|c|}
\hline \multirow{3}{*}{ Antimicrobial agent } & \multicolumn{4}{|c|}{ E. coli (12 isolates) } & \multicolumn{4}{|c|}{ Salmonellae (6 isolates) } \\
\hline & \multicolumn{2}{|c|}{ Sensitive } & \multicolumn{2}{|c|}{ Resistant } & \multicolumn{2}{|c|}{ Sensitive } & \multicolumn{2}{|c|}{ Resistant } \\
\hline & No. & $\%$ & No. & $\%$ & No. & $\%$ & No. & $\%$ \\
\hline Penicillin P & - & 0.0 & 12 & 100 & - & 0.0 & 6 & 100 \\
\hline Amoxycillin+Clavulonic acid & 7 & 58.33 & 5 & 41.66 & 3 & 50 & 3 & 50 \\
\hline Ciprofloxacin & 8 & 66.66 & 4 & 33.33 & 4 & 66.66 & 2 & 33.33 \\
\hline Clindamycin & - & 0.0 & 12 & 100 & - & 0.0 & 6 & 100 \\
\hline Streptomycin & 6 & 50 & 6 & 50 & 3 & 50 & 3 & 50 \\
\hline Gentamicin & 7 & 58.33 & 5 & 41.66 & 4 & 66.66 & 2 & 33.33 \\
\hline $\begin{array}{c}\text { Sulphamethoxazole }+ \\
\text { Trimethoprim }\end{array}$ & 6 & 50 & 6 & 50 & 3 & 50 & 3 & 50 \\
\hline Erythromycin & 1 & 8.33 & 11 & 91.66 & 1 & 16.66 & 5 & 83.33 \\
\hline Oxytetracycline & 3 & 25 & 9 & 75 & 2 & 33.33 & 4 & 66.66 \\
\hline
\end{tabular}


Table 7: Susceptibility of Gram positive (Staph. aureus and Streptococcus spp. isolates) to antimicrobial agents.

\begin{tabular}{|c|c|c|c|c|c|c|c|c|}
\hline \multirow[t]{3}{*}{ Antimicrobial agent } & \multicolumn{4}{|c|}{ Staph. aureus (34 isolates) } & \multicolumn{4}{|c|}{$\begin{array}{c}\text { Streptococcus spp. (20 } \\
\text { isolates) }\end{array}$} \\
\hline & \multicolumn{2}{|c|}{ Sensitive } & \multicolumn{2}{|c|}{ Resistant } & \multicolumn{2}{|c|}{ Sensitive } & \multicolumn{2}{|c|}{ Resistant } \\
\hline & No. & $\%$ & No. & $\%$ & No. & $\%$ & No. & $\%$ \\
\hline Penicillin P & 20 & 58.82 & 14 & 41.17 & 13 & 65 & 7 & 35 \\
\hline Amoxycillin+Clavulonic acid & 29 & 85.29 & 5 & 14.70 & 18 & 90 & 2 & 10 \\
\hline Ciprofloxacin & 27 & 79.41 & 7 & 20.58 & 15 & 75 & 5 & 25 \\
\hline Clindamycin & 26 & 76.47 & 8 & 23.52 & 12 & 60 & 8 & 40 \\
\hline Streptomycin & 17 & 50.0 & 17 & 50.0 & 8 & 40 & 12 & 60 \\
\hline Gentamicin & 18 & 52.94 & 16 & 47.05 & 14 & 70 & 6 & 30 \\
\hline Sulphamethoxazole + Trimethoprim & 12 & 35.29 & 22 & 64.70 & 10 & 50 & 10 & 50 \\
\hline Erythromycin & 25 & 73.52 & 9 & 26.47 & 13 & 65 & 7 & 35 \\
\hline Oxytetracycline & 24 & 70.58 & 10 & 29.41 & 14 & 70 & 6 & 30 \\
\hline
\end{tabular}

\section{DISCUSSION}

The safety of raw cow's milk is influenced by a combination of management and control measures along the entire dairy supply chain. Control of animal health, adherence to good milking practices and control over milking parlor hygiene are important in reducing the microbial load in raw milk. The modeling undertaken demonstrates that although the pathogen level may be very low in raw milk, there remains a risk of causing illness if consumed.

Inappropriate temperature control during the storage of raw milk following milking can lead to the growth of the majority of these pathogens, this may occur on farm, during transport, and packaging, and at various stages during marketing including transport, storage and in the home.

In Table (1), the results revealed that all of the examined raw cow's milk samples contained aerobic plate count (APC) with a mean value of $4.28 \times 10^{5}$ $\pm 1.23 \times 10^{5} \mathrm{cfu} / \mathrm{ml}$.

The aerobic plate count (APC) is of particular interest to the dairy farmers and processor. APC serves as a rough gauge of herd health farm sanitation efficacy and proper milk handling and storage temperature (Schalk et al., 2002). Milk contained APC above $1 \mathrm{x}$ $10^{5} \mathrm{cfu} / \mathrm{ml}$ are evidence of serious faults in production hygiene, whereas milk had APC values < $2 \times 10^{4}$ $\mathrm{cfu} / \mathrm{ml}$ reflect good hygienic practice (IDF, 1974).

In Table (2), the results revealed that 72 out of 100 examined raw cow's milk samples were positive for pathogenic bacteria of $E$. coli (12 isolates), Salmonellae (6 isolates), Staph. aureus (34 isolates) and Streptococcus species (20 isolates).
Result in Table (3) showed that E.coli isolates could be identified as $\mathrm{O}_{26}: \mathrm{H}_{11}, \mathrm{O}_{91}: \mathrm{H}_{21}, \mathrm{O}_{124}: \mathrm{H}_{30}, \mathrm{O}_{128}: \mathrm{H}_{2}(2$ isolates for each) and 4 isolates as $\mathrm{O}_{111}: \mathrm{H}_{2}$. Pathogenic E.coli are classified into specific groups based on their virulence properties, mechanisms of pathogenicity and clinical syndromes (Doyle et al., 1997). These groups include enteropathogenic E. coli, enterotoxigenic $E$. coli, enteroinvasive $E$. coli, enteroaggregative $E$. coli and enterohaemorrhagic $E$. coli.

Many synonyms are used to describe EHEC, including Shiga toxin-producing E.coli (STEC), Shiga-like toxin-producing E.coli (SLTEC), and Verocytotoxin-producing E.coli (VTEC). These organisms are often found in the feces of healthy cattle and as such their presence in raw milk is generally indicative of direct or indirect fecal contamination. However, organisms can be excreted through the udder when systemic infection resulted in mastitis. Martin and Beutin (2011) stated that recurrent outbreaks of life threatening human infections were attributed to STEC / EPEC contaminate milk and milk products. Serotype $\mathrm{O}_{128}$ has been found to be associated with infantile diarrhea among neonates and adult human patients suffering from gastroenteritis as reported by Nishikawa et al. (2002). The public health importance of isolated Enteropathogenic (EPEC) serovars had been attributed to its enterotoxin, which is implicated in causing gastroenteritis, epidemic children diarrhea, and sporadic diarrhea in children as well as food poisoning (Hassan and Afify, 2007).

Table (4) revealed that 6 isolates of Salmonellae could be isolated from the examined raw cow's milk samples and identified as 4 isolates of $S$. typhyimurium and 2 isolates of $S$. infantis. Salmonella 
spp. can be found in the intestinal tract of most warm and cold blooded animals. In cattle, the bacterium is carried by both healthy and diseased animals which shed in the feces and hence can contaminate raw milk. Fecal carriage prevalence has been reported up to $36.4 \%$ in cattle. International data showed the prevalence of Salmonellae in raw cow's milk ranging between $0-11.8 \%$. A small survey conducted in Western Australia in 2007 (183 samples) found a high prevalence of $E$. coli and coagulase-positive Staph. aureus, whilst Salmonella spp. were demonstrated at a prevalence of approximately $8 \%$ (Food Standard Australia Newzealand, 2009).

Salmonellosis is one of the most important zoonotic bacterial pathogen of food borne infection all over the world. The most important serotypes of Salmonellae are S.typhimurium and S.enteritidis (Hendriksen et al., 2011), and they can cause gastrointestinal disease. The main sources of transmission are water, eggs and raw foods (Karns et al., 2005).

Milk and milk products have been identified as the vehicle for transmission in approximately $5 \%$ of salmonellosis cases (CDC, 2000).

In Table (5) 34 isolates of Staph. aureus and 20 isolates of Streptococcus spp. could be isolated from the examined raw cow's milk samples and identified as St. agalactiae and St.dysgalactiae (6 isolates for each), 4 isolates of St. uberis and St.pyogenes and St.viridans (2 isolates for each). Staph. aureus is considered to be one of the most frequently occurring food borne pathogen worldwide and these result agree with Jahan et al. (2015) who could isolate Staph .aureus $(25.53 \%)$ from raw milk. The number of outbreaks and number of cases of staphylococcal gastroenteritis is much higher than several other microbial food borne diseases outbreaks (Jay, 2000). Streptococcus species are major mastitis pathogens along with Staph. aureus and coliforms. Some of the Streptococcus spp. as for example St. agalactiae in cows are animal associated and well adapted to their mammary glands whereas others (St. dysgalactiae, St. uberis, St. bovis, St. oralis, etc.) are environmental strains acting as opportunistic pathogens (Botrel et al., 2010). However, various studies have shown that such environmental Streptococci are becoming increasingly resistant to many antimicrobial agents and are known to be reservoirs of resistant genes, transferring different resistant traits to more pathogenic organisms (Bryskier, 2002).

Higher incidence of Staph. aureus in the examined samples revealed unsanitary conditions in the cattle herd resulted in appearance of mastitic animals, improper washed milking utensils or tanks, poor handler's hygiene and lengthy delivery time. Jayarao et al. (2006) found 13\% (32/248) of bulk milk samples contained more than one species of bacterial pathogen in this respect and Rohrbach (1992) reported a higher percentage $(25 \%)$ of bulk milk samples contained one or more pathogenic bacteria.

Table $(6,7)$ revealed that E.coli, Salmonellae, Staph. aureus and Streptococcus spp. were sensitive to Ciprofloxacin (66.66\%); Ciprofloxacin, Gentamicin (66.66\% each); Amoxycillin+Clavulonic acid (85.29\%) and Amoxycillin+Clavulonic acid (90\%), respectively and were resistant to Penicillin $\mathrm{P}$, Clindamycin (100\% each); Penicillin P, Clindamycin (100\% each); Sulphamethoxazole+Trimethoprim $(64.70 \%)$ and Streptomycin (60\%), respectively. Unfortunately, indiscriminate prescribing of antibiotics in veterinary is so high and in a report from Netherland, $300000 \mathrm{~kg}$ of antibiotics are used annually on veterinary prescription in animals (Vanden Bogaard, 1997). This high amount of antibiotics can be kept in animals and lead to antibiotics resistance of bacteria. These bacteria contain resistant genes shedding with milk and meat causing drug resistance in human.

There are two conditions needed for antibiotic resistance to be developed in bacteria. First, the organism must come into contact with the antibiotic levels below the strains Minimum Inhibitory Concentrations (MICS). Second, resistance against the agent must develop, along with a mechanism to transfer it to daughter organisms or directly to other members of the same species (Noble et al., 1992).

The resistance pattern observed in isolated organisms should be of concern as it is raised food safety and ethical issues. Resistant strains are potential causes of infection, also ingestion of resistant microorganisms through food and water could be resulted in selection of resistant strains in humans (Levy, 1997).

\section{CONCLUSION AND RECOMMENDATIONS}

Results obtained in this study confirmed the occurrence of E.coli, Salmonellae, Staph. aureus and Streptococcus spp. in the examined raw cow's milk samples which may be attributed to lack of sanitary conditions, so raw milk should be considered as a vehicle for transmission of potentially pathogenic bacteria.

It is important to handle food in such a way that microorganisms present do not have chance to multiple and to prevent food from becoming contaminated with other microorganisms (WHO, 2001). Improving hygienic practices during milking routine and careful handling of cow during milking should be followed to limit the spread of such bacteria to humans and less than $100 \mathrm{cell} / \mathrm{ml}$ milk of bacterial counts can be achieved if some better hygienic practices implemented, in addition introduction of cooling system for the milk during 
production, transportation and during distribution process. Increase awareness of public health of producers, the seller and the consumer. Also, antibiotic sensitivity tests should be done to the isolated bacteria to detect effective antibiotic in treatment for saving our time, costs of treatment and decreasing our losses.

\section{REFERENCES}

APHA (American Public Health Association) (2004): Compendium of Methods for the Microbiological Examination of Food. 17th ed. Washington D.C. USA.

Bailey, W.R. and Scott, E.G. (1990): Diagnostic Microbiology. A textbook for isolation and identification of pathogenic microorganisms. The C.V. osby Company Publishing. St. Louis, Tonasto.

Botrel, M.A.; Haenni, M.; Morignat, E.; Sulpice, P.; Madec, J.Y. and Calavas, D. (2010): Distribution and antimicrobial resistance of clinical and subclinical mastitis pathogens in dairy cows in Rhône-Alpes, France. Food borne Pathogens and Disease, 7: 479-487.

Brooks, I.B.; Luster, G.A. and Easterly, D.B. (1991): A procedure for rapid determination of the major cations in milk by atomic absorption spectrophotometry. At. Absorpt. Newsl., 9: 93.

Bryskier, A. (2002): Viridians group streptococci: A reservoir of resistant bacteria in oral cavities. Clin. Microbiol. Infect., 8: 65-69.

Carter, G.R. and Cole, J.R. (1990): Diagnostic procedures. In Veterinary Bacteriology and Mycology $5^{\text {th }}$ ed. New York: Academic Press Inc., Boston, Sydney, Tokyo, Toronto.

CDC (Center for Disease Control) (2000): Surveillance for food borne disease outbreaks - United States, 1993-1997. Morb. Mortal. Wkly. Rep. 49: 1-64.

Devriese, L.A.; Haesebrouck, F.; Hommez, H. and Vandermeersch, R. (1997): A 25-year survey of antibiotic susceptibility testing in Staphylococcus aureus from bovine mastitis in Belgium, with special reference to penicillinase. Vlaams Diergeneeskundig Tijdschrift, 66: 170-173.

Doyle, M.P.; Zhao, T.; Meng, J. and Zhao, S. (1997): Escherichia coli O157H:7. In: Doyle, M.P., Beuchat, L.R., and Montville, T.J. eds. Food Microbiology: Fundamentals and Frontiers. ASM Press, Washington, USA, pp.: 171-191.

EFSA (European Food Safety Authority) (2010): The community summary report on trends and sources of zoonoses, zoonotic agents and food borne outbreaks in the European Union in 2008. EFSA. 8(1): 1496.

Food Standard Australia Newzealand (2009): Microbiological risk assessment of raw cow milk. Available on http://www.foodstandards. gov.au/_srcfiles/DAR_P296_Dairy_PPPS_Att
ach2\%20Parts\%20AB.pdf\#search=\%22Risk\% 20Profile $\% 22$.

Hassan, G.M. and Afify, S.H. (2007): Occurrence of some pathogenic microorganisms in kareish cheese and their public health significance. BS. Vet. Med. J., $5^{\text {th }}$ Sci. Conf., 142-150.

Hendriksen, R.S.; Vieira, A.R.; Karlsmose, S.; Lo Fo Wong, D.M.; Jensen, A.B. and Wegener, H.C. et al. (2011): Global monitoring of Salmonella serovar distribution from the world health organization global food borne infections network country data bank: results of quality assured laboratories from 2001 to 2007. Food Borne Pathogens and Diseases, 8(8): 1-14.

IDF (International Dairy Federation) (1974): Bacteriological quality of cooled bulk milk. Doc. No. 83, 41 Square Vergote, B-1030, Brussels, Belgium.

Jahan, M.; Rahman, M.; Parvej, Md. S.; Chowdhury, S.Md.Z.H.; Haque, Md.E.; Talukder, Md.A. and Ahmed, S. (2015): Isolation and characterization of Staphylococcus aureus from raw cow milk in Bangladesh. J. Adv. Vet. Anim. Res., 2(1): 49-55.

Jay, J.M. (2000): Staphylococcal gasreoenteritis. In Modern Food Microbioloy, $3^{\text {rd }}$ ed. pp.: 437458. New York: Van Nostrand Reinhold Company Inc.

Jayarao, B.M.; Donaldson, S.C.; Straley, B.A.; Sawant, A.A.; Hegde, N.V. and Brown, J.L. (2006): A survey of food borne pathogens in bulk tank milk and raw milk consumption among farm families in Pennsylvania. J. Dairy Sci., 89(7): 2451-2458.

Karns, J.S.; Van Kassel, J.S.; McKluskey, B.J. and Perdue, M. (2005): Prevalence of Salmonella enteric in bulk tank milk from US dairies as determined by Polymerase Chain Reaction. J. Dairy Sci., 88: 3475-3479.

Kauffman, G. (1974): Kauffmann white scheme. J. Acta. Path. Microbiol. Sci., 61: 385.

Kok, T.; Worswich, D. and Gowans, E. (1996): Some serological techniques for microbial and viral infections. In Practical Medical Microbiology (Collee, J.; Fraser, A.; Marmion, B. and Simmons, A., eds.), $14^{\text {th }}$ ed., Edinburgh, Churchill Livingstone, UK.

Latorre, A.A; Van Kessel, Jo.A.S.; Karns, J.S.; Zurakowski, M.J.; Pradhan, A.K.; Zadoks, R.N.; Boor, K.J. and Schukken, Y.H. (2009): Molecular ecology of Listeria monocytogenes: evidence for a reservoir in milking equipment on a dairy farm. Applied and Environmental Microbiol., 75: 1315-1323.

Levy, B. (1997): Antibiotic resistance. An Ecological Imbalance. Ciba Foundation Symposium, 207:1-9.

Macfaddin, J.F. (2000): Biochemical testes for identification of medical bacteria. Lippincott Williams \& Wilkins; Philadelphia. 
Mackie, T.J. and McCartney, J.E. (1989): Practical Medical Microbiology $13^{\text {th }}$ ed. Churchill Living stone Publishing, Edinburg, London, Melburne and New York.

Madigan, M.T.; Martiko, J.M. and Parker, J.M. (2000): Antibiotic sensitivity. J. Biology of Microorganisms, 44: 3249-3256.

Marco, M.L. and Wells-Bennik, M. (2008): Impact of bacteriological genomics on determining quality and safety in the dairy production chain. International Dairy J., 18: 486-495.

Martin, A. and Beutin, L. (2011): Characteristics of Shiga toxin-producing Escherichia coli from meat and milk products of different origins and association with food producing animals as main contamination sources. International J. Food Microbiol., 146: 99-104.

Martineau, F.; Picard, F.J.; Roy, P.H.; Ouellette, M. and Bergeron, M.G. (2000): Species-specific and ubiquitous DNA-based assays for rapid identification of Staph. aureus. J. Clin Microbiol., 36: 618-623.

Mekonnen, A.; Mahindra, P. and Moses, N. (2011): Isolation and identification of Staphylococcus species from raw bovine milk in Debre Zeit. Ethiopia Medwell J., 4(2): 45-49.

NCCLS (National Committee for Clinical Laboratory Standards) (2002): Performance standards for antimicrobial susceptibility testing. Supplement M100-S11. Villanova, PA, USA.

Nishikawa, Y.; Zhou, Z.; Hase, A.; Ogasawara, J.; Kitase, T.; Abe, N.; Nakamura, H.; Wada, T.; Ishii, E.; Haruki, K. and the Surveillance Team (2002): Diarrheagenic Escherichia coli isolated from stools of sporadic cases of diarrheal illness in Osaka city, Japan between 1997 and 2000: Prevalence of Entero aggregative E. coli heat stable enterotoxin 1 gene - possessing E. coli. Japanese J. infectious diseases, 55: 182-190.

Noble, W.; Vurani, Z. and Cree, A. (1992): Cotransfer of Vancomycin and other resistance genes to Enterococcus fecalis NCTC 12201 to Staphylococcus aureus. Microbiological letters, 93: 195-198.

Quinn, P.; Carter, M.; Markey, B. and Carter, G. (2004): Clinical Veterinary Microbiology. $6^{\text {th }}$ ed., Mosby, Edinburgh, London, NewYork, Philadelphia, St. Louis, Sydney, Toronto.

Rohrbach, B.W.; Draughon, F.A.; Davidson, P.M. and Oliver, S.P. (1992): Prevalence of Listeria monocytogenes, Campylobacter jejuni, Yersinia enterocolitica, and Salmonella in bulk tank milk: risk factors and risk of human exposure. J. Food Prot., 55:93.

Schalk, G.; Lotem, M. and Schkken, Y.H. (2002): Trends in somatic cell count, bacterial count and antibiotic residues violation in New York State during 1999-2000. J. Dairy Sci., 85: 782789.

Thatcher, F.S and Clark, D.S. (1978): Microorganisms in foods. ICMSF Academic press, New York.

Vanden Bogaard, A.E. (1997): Antimicrobial resistance- relation to human and animal exposure to antibiotics. J. Antimicrobial Chemotherapy, 40: 453-454.

WHO (World Health Organization) (2001): Identification and classification of consumer food-handling behaviors for food safety education. J. American Dietetic Association, 101: 1326-1332, 1337-1339.

Wood, C.A. (1992): Significant infection caused by Staphylococcus warneri. J. Clin. Microbiol., 30: 2216-2217.
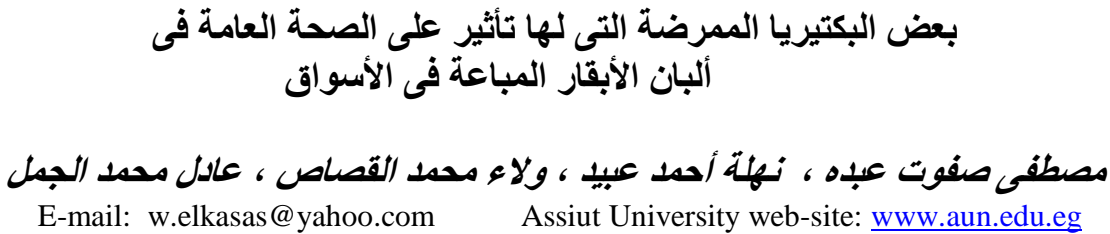

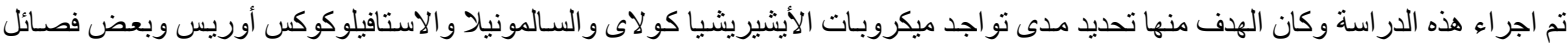

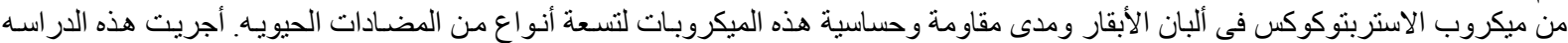

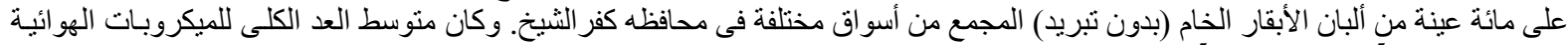

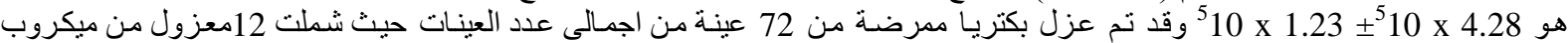

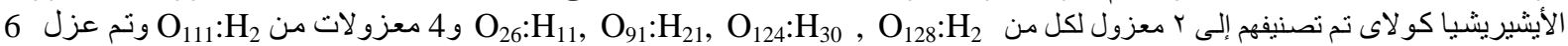

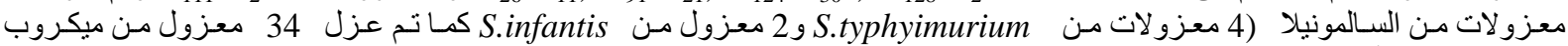

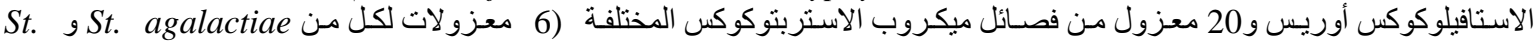

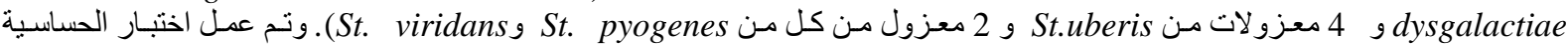

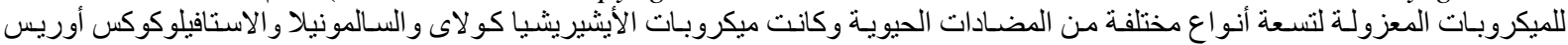

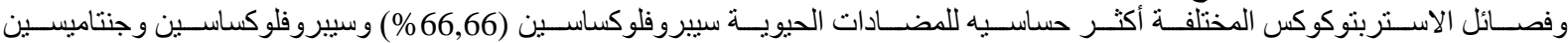

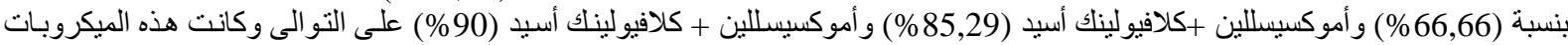

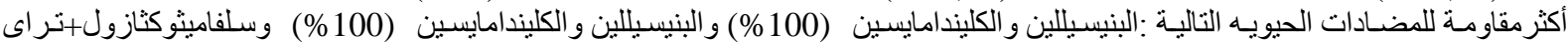

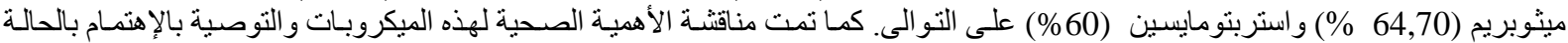

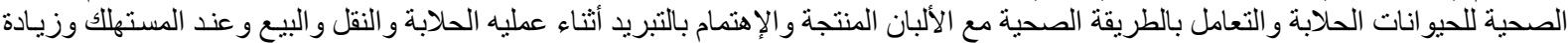

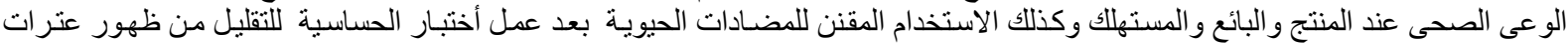

